\title{
Article \\ An Extinct New Rail (Gallirallus, Aves: Rallidae) Species from Rapa Island, French Polynesia ${ }^{\dagger}$
}

\author{
Rodrigo B. Salvador ${ }^{1}\left(\mathbb{D}\right.$, Atholl Anderson ${ }^{2}\left(\mathbb{D}\right.$ and Alan J. D. Tennyson ${ }^{1, * \mathbb{C}}$ \\ 1 Museum of New Zealand Te Papa Tongarewa, Wellington 6011, New Zealand; salvador.rodrigo.b@gmail.com \\ 2 Department of Archaeology and Natural History, Australian National University, Canberra 2600, Australia; \\ atholl.anderson@anu.edu.au \\ * Correspondence: alant@tepapa.govt.nz \\ † urn:lsid:zoobank.org:pub:B77575A7-DEFA-43A5-BAC9-A79BC76C301C.
}

check for

updates

Citation: Salvador, R.B.; Anderson, A.; Tennyson, A.J.D. An Extinct New Rail (Gallirallus, Aves: Rallidae) Species from Rapa Island, French Polynesia. Taxonomy 2021, 1, 448-457. https://doi.org/10.3390/ taxonomy1040032

Academic Editor:

Mathias Harzhauser

Received: 24 November 2021 Accepted: 15 December 2021 Published: 20 December 2021

Publisher's Note: MDPI stays neutral with regard to jurisdictional claims in published maps and institutional affiliations.

Copyright: (c) 2021 by the authors. Licensee MDPI, Basel, Switzerland. This article is an open access article distributed under the terms and conditions of the Creative Commons Attribution (CC BY) license (https:// creativecommons.org/licenses/by/ $4.0 /)$.
Abstract: A new species of rail, Gallirallus astolfoi sp. nov., is described from Rapa Island (Rapa Iti), French Polynesia. The holotype (and single known specimen) is a left tarsometatarsus recovered from Tangarutu Cave. This rail species was apparently endemic to Rapa Iti and potentially flightless. It became extinct after human colonisation of the island.

Keywords: endemic species; flightlessness; Gallirallus astolfoi sp. nov.; Holocene; Rapa Iti

\section{Introduction}

Rapa Island, also known as Rapa Iti, is a subtropical island in the South Pacific and the southernmost inhabitable island of French Polynesia. It has an area of circa $38 \mathrm{~km}^{2}$ and its origin as a volcanic caldera resulted in a jagged topography that rises abruptly from the sea, with its highest point being Mont Perau at $650 \mathrm{~m}$ above sea level [1]. The first Polynesian settlers most likely arrived on Rapa Iti between 1100 and 1200 CE and the first Europeans in 1791 CE [2-4].

The island fauna was dominated by birds, with no native mammals or terrestrial reptiles [5]. Among other species, Rapa Iti is home to the critically endangered Rapa fruitdove Ptilonopus huttoni Finsch, 1874, while the Rapa shearwater Puffinus myrtae Bourne, 1959 , once present on the island, is now confined to offshore islets.

A number of bird bones from archaeological sites are also known from Rapa Iti, which were studied by Tennyson \& Anderson [5]. Among the species those authors identified was a "Gallirallus-type rail", which they hypothesized could be an endemic form and commented that further analysis was necessary to determine its identity. The occurrence of island-endemic species, particularly when reduced flight capability (or flight loss) is in play, is a common occurrence in many genera of Rallidae worldwide [6-12]. This is a particularly widespread phenomenon on the islands of the Caribbean and the South Pacific, including several species known only from Quaternary fossil material [8,13-16].

In the present paper, we analyse the rail material of Tennyson \& Anderson [5] from Rapa Iti, comparing it to other known living and extinct Gallirallus spp. and describing it as a new species.

\section{Material \& Methods}

The material of the "Gallirallus-type rail" available from the study of Tennyson \& Anderson [5] is a single left tarsometatarsus, housed in the Museum of New Zealand Te Papa Tongarewa (NMNZ, Wellington, New Zealand). It is part of a large series of animal remains (mostly fish) recovered from archaeological sites along the coast of Rapa Iti. The rail bone is very well preserved and was found in Tangarutu Cave (in Section S1, described in [17]). For more details on the site and depositional environment, see [17]. 
The new tarsometatarsus was compared to specimens of living and extinct rails described in the literature, with a focus in the South Pacific taxa of Gallirallus Lafresnaye, 1841, as well as specimens in the collection of the NMNZ (refer to Appendix A for a full list). A digital calliper $(0.01 \mathrm{~mm}$ precision, rounded to the nearest $0.1 \mathrm{~mm}$ ) was used to take the following measurements of the specimen of interest and comparative material (Table 1): total length, distal width, proximal width, mid-shaft width, and mid-shaft depth. Measurements of further species for comparison were taken from the literature (Table 1). The osteological nomenclature used here follows [18-20].

The species classification in Gallirallus used here follows [21]. A recent phylogenetic study [22] has split Gallirallus Lafresnaye, 1841 into four genera. For those authors, Gallirallus contains only two species: the weka G. australis and the New Caledonian rail G. lafresnayanus. They classified the invisible rail G. wallacii into the monospecific genus Habroptila G.R. Gray, 1861, and erected a further monospecific genus, Aptenorallus Kirchman, McInerney, Giarla, Olson, Slikas \& Fleischer, 2021 (formally described in [23], a corrigendum to that publication), solely for the Calayan rail G. calayanensis. All remaining species were allocated to the genus Hypotaenidia Reichenbach, 1853 by those authors. While the taxonomy of this group remains in flux, we retain all species in Gallirallus (Table 1). 


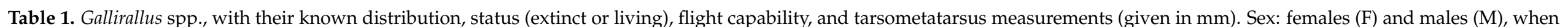

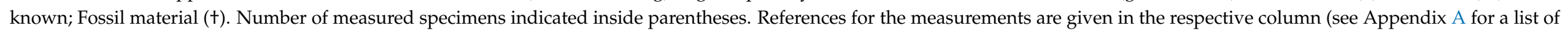
specimens measured for the present study).

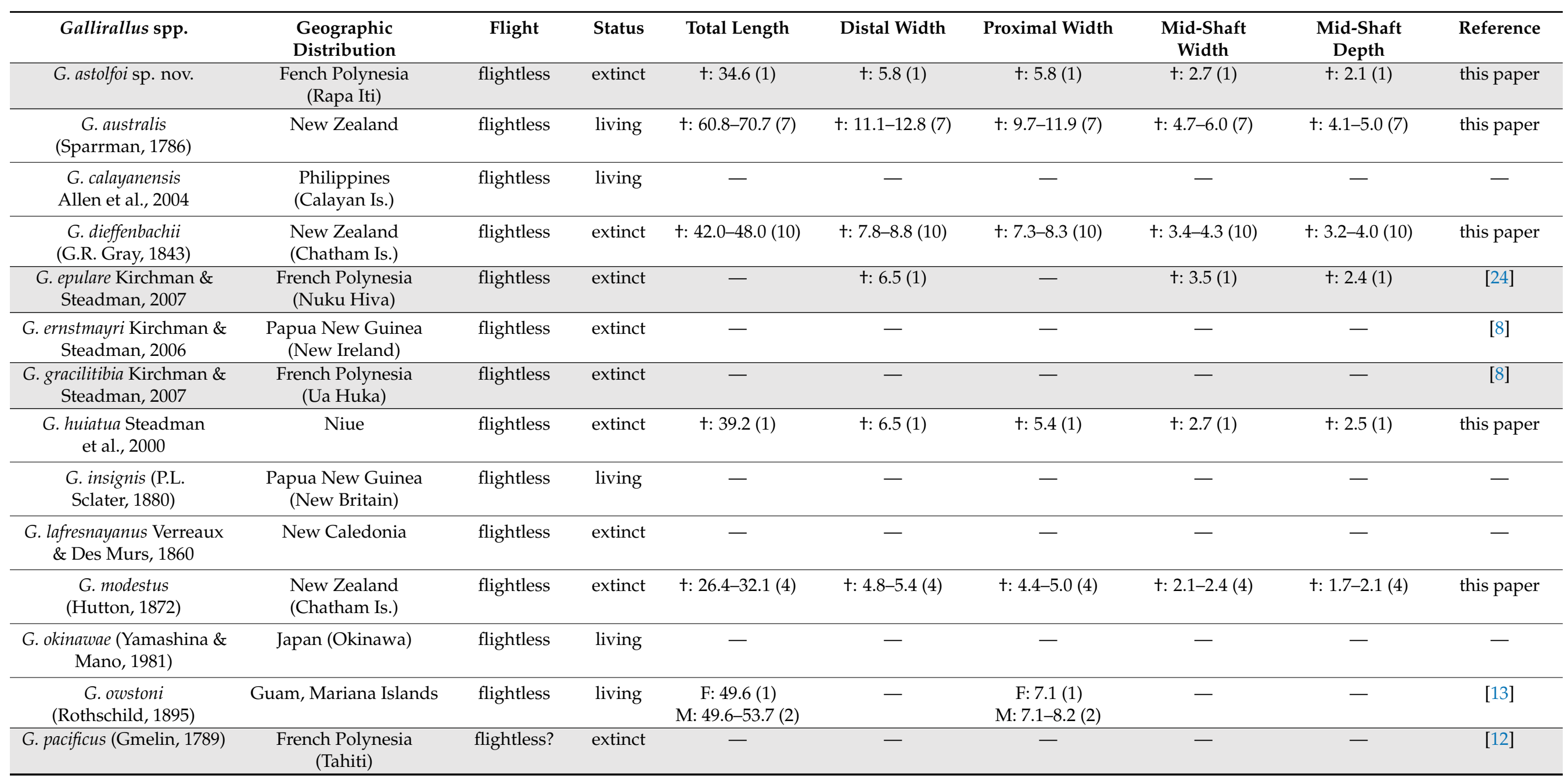


Table 1. Cont.

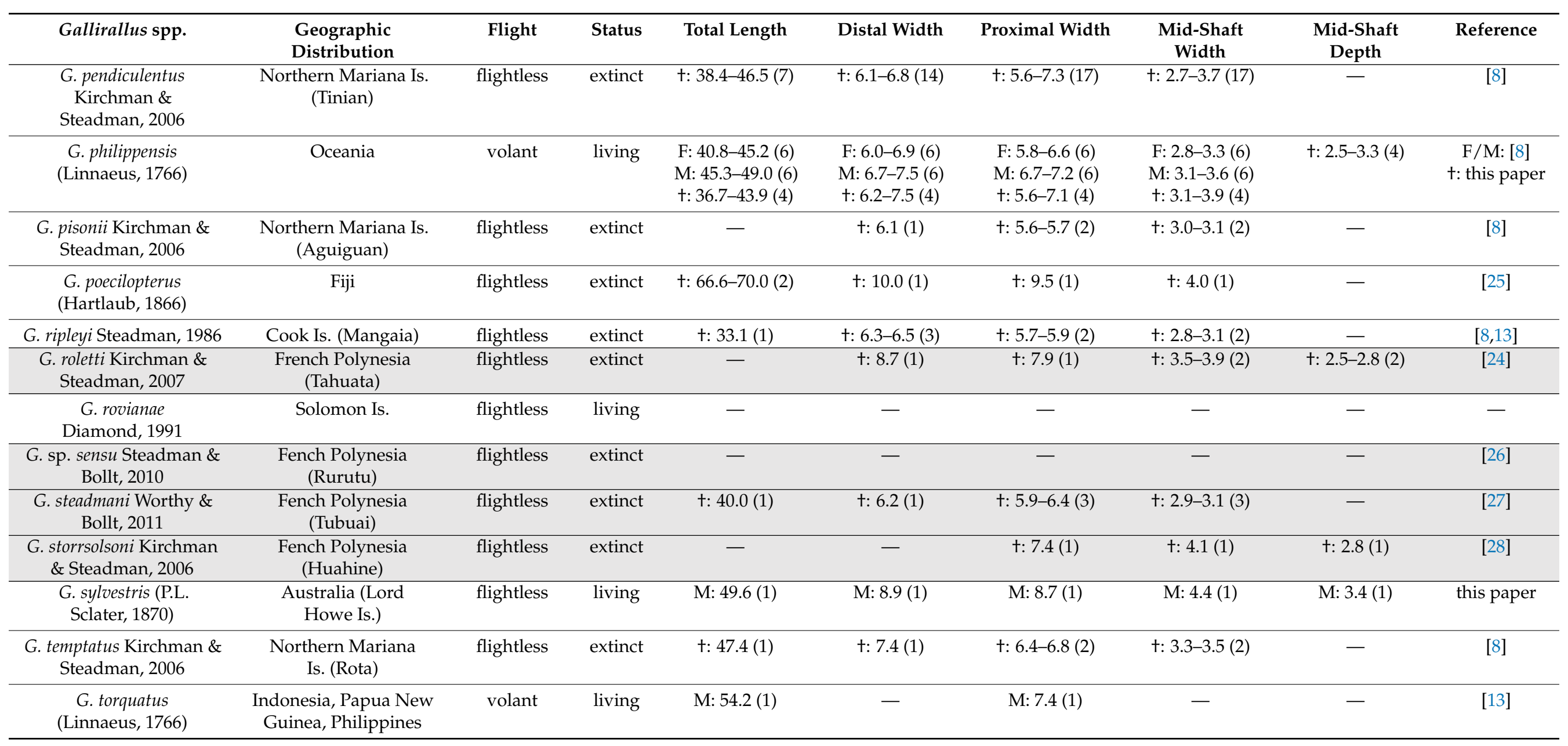


Table 1. Cont.

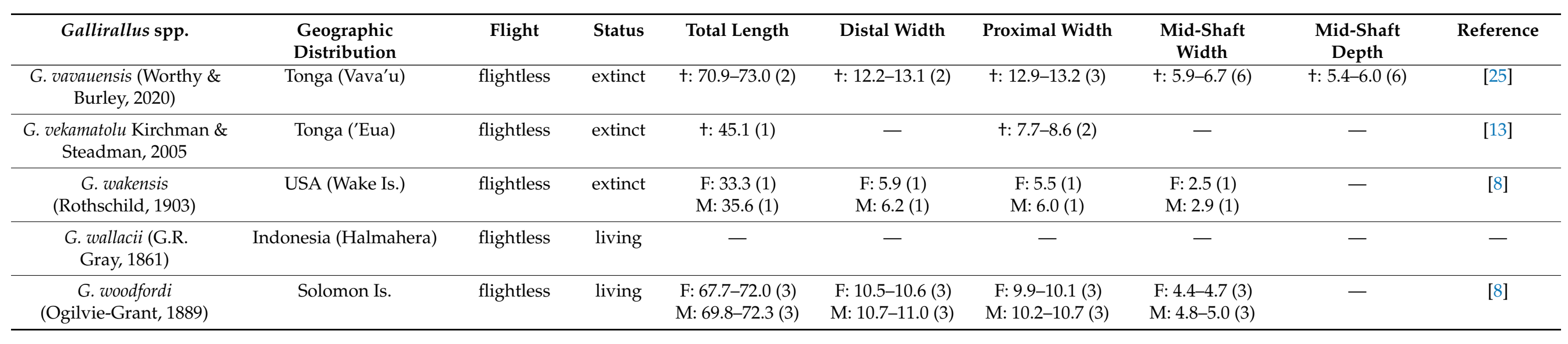




\title{
3. Systematics
}

The morphology of the Rapa Iti tarsometatarsus indicates that it could only belong to the Order Gruiformes and family Rallidae, given the presence of two open tendinal canals, one distal foramen, and the tendinal bridge [19]. More specifically, the Rapa Iti fossil can be allocated to the genus Gallirallus due to the following diagnostic features of the tarsometatarsus (as per [8]: p. 8): "corpus tarsometatarsi much wider than deep; medial sulcus hypotarsi not enclosed; fossa parahypotarsalis medialis shallow in proximal aspect; fossa metatarsi I short and shallow; crista plantaris mediana slopes gradually (not steeply) to hypotarsus; distal end of trochlea metatarsi tertii sloped toward medial trochlea; cotyla medialis is rectangular in proximal aspect with flat (not rounded) dorsal margin". According to our comparative analysis with tarsometatarsi of living and extinct species of Gallirallus (see below), we are confident in assigning the present fossil to a new species, apparently endemic to Rapa Iti.

\author{
Family Rallidae \\ Genus Gallirallus Lafresnaye, 1841 \\ Gallirallus astolfoi sp. nov. \\ (Figure 1)
}

rail (cf. Gallirallus): Tennyson \& Anderson, 2012: 108.

ZooBank reg. nr.: urn:lsid:zoobank.org:act:F606759B-4C48-491E-93F0-0E8C018B3B97.

Holotype: NMNZ S.044399 (left tarsometatarsus; A. Anderson col. 21/vii/2002).

Type locality: French Polynesia, Rapa Island (Rapa Iti), Tangarutu Cave, Section S1 $(30-40 \mathrm{~cm})$.

Etymology: The specific epithet honours Astolfo, one of Charlemagne's fictional paladins. In the epic Orlando Furioso, Astolfo becomes trapped on a remote island because of the sorceress Alcina.

Diagnosis: Tarsometatarsus small (ca. $34.5 \mathrm{~mm}$ long), of delicate appearance, with narrow and shallow shaft, and narrow trochleae (particularly the trochlea metatarsi II).

Differential diagnosis: The tarsometatarsus of Gallirallus astolfoi sp. nov. (Figure 1) is considerably smaller than most other congeners (Table 1), with the exception of $G$. ripleyi from the Cook Islands and G. wakensis from the Wake Island, both flightless and extinct $[8,24]$. Its shaft, however, is proportionately much narrower and shallower, which gives the bone a more delicate appearance. The Chatham Island rail G. modestus (previously classified into its own genus, Cabalus) is much smaller and its tarsometatarsi have a more compact appearance.

The single known tarsometatarsus of G. huiatua from Niue is similar to that of $G$. astolfoi sp. nov. in its delicate appearance (i.e., shaft width and depth, and trochleae width), but it is more elongate. The tarsometatarsus of G. pendiculentus from the Northern Marianas and of G. steadmani from Tubuai, French Polynesia, are similar in shape to G. astolfoi sp. nov. but are much larger (Table 1). Furthermore, G. steadmani apparently has proportionately narrower trochlea (trochlea metatarsorum III and IV), though that could have been overemphasized by the sub-optimal preservation of the specimens ([27]: figure $4 \mathrm{~L}$ ).

In comparison with larger congeners, the tarsometatarsus of G. astolfoi sp. nov. is more delicate, with its proportionately narrower and shallower mid and distal shaft, as well as its narrower trochleae. Compared with G. philippensis and other species from French Polynesia, namely G. epulare from Nuku Hiva, G. roletti from Tahuata, and G. storrsolsoni from Huahine, the latter two, in particular, have much stouter tarsometatarsi, with a wider mid-shaft ([24]: figure 6A,B). Furthermore, the trochlea of digit 2 (trochlea metatarsi II) of G. astolfoi sp. nov. is less expanded than in G. philippensis and some island-endemic congeners such as $G$. roletti and G. dieffenbachii. 


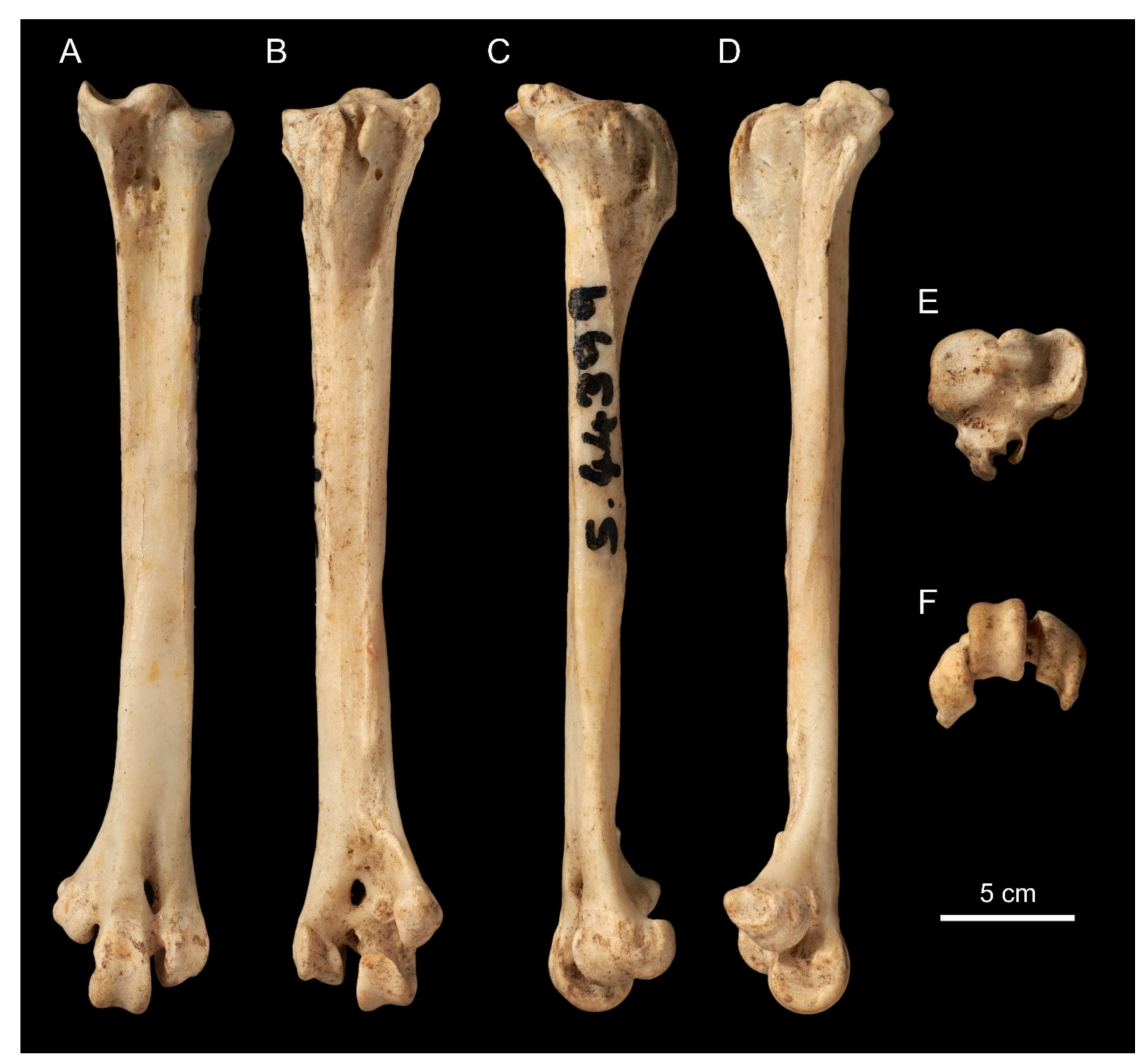

Figure 1. Left tarsometatarsus (holotype, NMNZ S.044399) of Gallirallus astolfoi sp. nov. in different views: (A) anterior, (B) caudal, (C) lateral, (D) medial, (E) proximal, (F) distal.

There are two further extinct endemic flightless species from French Polynesia: $G$. gracilitibia from Ua Huka and G. pacificus from Tahiti $[12,24]$ (Table 1). No tarsometatarsi are known for these taxa, which precludes comparison with G. astolfoi sp. nov. Nevertheless, there is little chance that they could be conspecific as these islands are respectively $2100 \mathrm{~km}$ and $1200 \mathrm{~km}$ away from Rapa Iti. The only other Rallidae species on Rapa Iti is the widespread and much smaller spotless crake, Zapornia tabuensis (Gmelin, 1789) [5]. There is a further undescribed fossil species, Gallirallus sp. of [26], that is endemic to Rurutu (and extinct), though there is no published information or photographs available.

\section{Discussion}

Tennyson \& Anderson [5] identified four extinct species on Rapa Iti, among which is Gallirallus astolfoi sp. nov. On the tropical Pacific islands, extinction of the avifauna is assigned to anthropogenic impact and the numbers of extinct land bird species are dominated by rails $[29,30]$. More specifically in French Polynesia (albeit similar to many other islands worldwide), the main causes of population crashes and extinctions are predation of adults, chicks and eggs by mammals (particularly humans, Pacific rats Rattus exulans, and feral cats), alongside land alteration and habitat destruction by humans and feral goats [3,31,32]. While Pacific rats were introduced by Polynesians, cats and goats (alongside cattle, pigs and dogs) were introduced by Europeans [5,32-34].

While we have little direct evidence to ascertain whether Gallirallus astolfoi sp. nov. was hunted for food by humans, this seems probable. While most of the animals eaten by the inhabitants of rock shelters like Tangarutu Cave, where the present rail bone was found, seem to have been fish [2], birds were potentially consumed too. Seven species of birds were reported from Section S1 of Tangarutu Cave alone (from a total of 15 bird taxa from all archaeological sites on Rapa Iti) [5]. While there was no clear evidence of the bones being deposited as part of a midden rather than by natural accumulation (i.e., no signs of butchery or charring), the cultural context of the sites is clear [5]. Occupation of Tangarutu 
Cave likely dates back to between 1400 and 1600 CE [2]. Thus, the deposit happened after human settlement; furthermore, in the case of Tangarutu Cave, this age is also supported by the presence of rat bones in Section S1.

Given its smaller size in comparison to volant congeners and its presence on a remote island, we hypothesize that Gallirallus astolfoi sp. nov. had reduced flight capacity or, potentially, it was flightless. As mentioned above, flightlessness is a common feature in Rallidae, occurring independently in several genera and different species within the same genus. Earlier workers $[11,35]$ hypothesized that flightlessness in rails was a neotenic condition involving little genetic modification and thus able to occur through rapid evolution. Later works offered support to the heterochrony hypothesis, arguing that a change in timing of development could lead to the observed allometric differences in rails (see [9] for a review). Likewise, molecular clock estimates have supported the hypothesis that evolution of flightless Gallirallus species in Oceania has been rapid after the appearance of the genus in the Late Miocene [22,36-38]. Furthermore, phylogenetic studies offered evidence that flightlessness can evolve prior to reproductive isolation [38].

Only two out of circa 30 species of Gallirallus are volant and widespread (Table 1); most species are flightless and endemic to single islands (or multiple islands, in cases where they were formerly connected due to the lower sea levels of the late Pleistocene [28]). Of the two volant species, G. philippensis is the most widespread and it is hypothesized that breakaway populations of it have colonized many islands throughout the Pacific, giving rise to the endemic forms [8]. As such, it is notable that most of these endemic species evolved the common pattern of flightlessness plus increased body size (e.g., G. roletti in French Polynesia; Table 1). It has been argued that loss of flight was typically related to increased body size, which could mean that such a combination has a greater selective advantage and/or is ontogenetically more parsimonious [9]. Nevertheless, Gallirallus astolfoi sp. nov. is one of the few species of the genus that apparently underwent a decrease in size (Table 1). Therefore, despite the relatively similar areas and environments of these islands, it seems that different selective pressures towards local optima were in play on each of them and that Gallirallus defies generalizations of insular gigantism/dwarfism (cf. [9]).

\section{Conclusions}

Gallirallus astolfoi sp. nov. from Rapa Iti is the seventh extinct species in the genus to be described from French Polynesia (Table 1), excluding the potential undescribed one mentioned above. Excluding the volant G. philippensis, the species geographically closest to G. astolfoi sp. nov. is G. steadmani from Tubuai, ca. $700 \mathrm{~km}$ NW from Rapa Iti. As new specimens continue to be discovered and described, the scenario of a multitude of endemic rail species across the Pacific Islands is becoming more evident, offering further evidence in support of the above-mentioned hypothesis $[8,30]$. Likewise, the list of species extinct after human contact during the past millennia is becoming more extensive, adding to the corpus of data on the demise of insular faunas.

Author Contributions: Conceptualization, methodology, R.B.S. and A.J.D.T.; investigation, data curation, writing - original draft preparation, R.B.S.; writing-review and editing, R.B.S., A.A. and A.J.D.T.; supervision, A.A. and A.J.D.T. All authors have read and agreed to the published version of the manuscript.

Funding: This research received no external funding.

Data Availability Statement: All data can be found within the article.

Acknowledgments: We are very grateful to Jean-Claude Stahl (NMNZ) for photographs of the specimen; to Christopher Milensky (Smithsonian National Museum of Natural History, Washington, DC, USA) for comparative photos of G. wakensis; to Douglas Kennett and Eric Conte for co-organizing the fieldwork in which the present fossil was discovered; and to the two anonymous reviewers for their helpful comments and suggestions.

Conflicts of Interest: The authors declare no conflict of interest. 


\section{Appendix A}

The following specimens of Rallidae from the NMNZ collection were used for comparison. The list is arranged alphabetically by species name, with acronym (NMNZ) omitted from registration numbers for brevity. Measured specimens (used in Table 1) are identified by an asterisk $(*)$.

Capellirallus karamu Falla, 1954: S.023241. Diaphorapteryx hawkinsi (Forbes, 1892): OR.007997. Fulica atra australis Gould, 1845: OR.024566. Fulica chathamensis Forbes, 1892: S.026519. Fulica prisca Hamilton, 1893: S.033721. Gallinula hodgenorum (Scarlett, 1955): S.033724. Gallinula tenebrosa Gould, 1846: OR.024520. Gallinula ventralis Gould, 1837: OR.022100. Gallirallus australis australis (Sparrman, 1786): OR.014994. Gallirallus australis greyi (Buller, 1888): S.00573, S.023353*, S.023387*, S.027815*, S.034078*, S.042193*, S.045588*. Gallirallus australis hectori (Hutton, 1873): OR.0025361. Gallirallus australis scotti (OglivieGrant, 1905): OR.018327. Gallirallus dieffenbachii (G.R. Gray, 1843): S.026625*, S.026924*, S.026943*, S.027616*, S.027766* S.030037, S.031762*, S.032013*, S.032092*, S.033198*, S.044038* Gallirallus huiatua Steadman et al., 2000: S.037708* (holotype). Gallirallus modestus (Hutton, 1872): S.026258* S.026967* S.027607*, S.031303*, S.031755. Gallirallus philippensis assimilis (G.R. Gray, 1843): OR.023821. Gallirallus philippensis goodsoni (Mathews, 1911): S.035228*. Gallirallus philippensis mellori (Mathews, 1912): S.045796*. Gallirallus philippensis sethsmithi (Mathews, 1911): S.038224*, S.038383*. Gallirallus sylvestris (P.L. Sclater, 1870): S.027218a* Lewinia muelleri (Rothschild, 1893): OR.025556. Porphyrio mantelli (Owen, 1848): S.028440. Porphyrio hochstetteri (A.B. Meyer, 1883): OR.024641. Porphyrio melanotus melanotus Temminck, 1820: OR.024252. Zapornia pusilla affinis (J.E. Gray, 1845): OR.024417. Zapornia tabuensis tabuensis (Gmelin, 1789): OR.020984, S.044596.

\section{References}

1. Anderson, A.; Kennett, D.J.; Conte, E. Archaeological research on Rapa Island, French Polynesia. Terra Aust. 2012, 37, 7-23.

2. Anderson, A.; Kennett, D.J.; Conte, E. The prehistory of Rapa Island. Terra Aust. 2012, 37, 247-256.

3. Kennett, D.; Anderson, A.; Prebble, M.; Conte, E.; Southon, J. Prehistoric human impacts on Rapa, French Polynesia. Antiquity 2006, 80, 340-354. [CrossRef]

4. Richards, R. The earliest foreign visitors and their massive depopulation of Rapa-iti from 1824 to 1830. J. Société Océanistes 2004, 118, 3-10. [CrossRef]

5. Tennyson, A.; Anderson, A. Bird, reptile and mammal remains from archaeological sites on Rapa Island. Terra Aust. 2012, 37, 105-114.

6. Alcover, J.A.; Pieper, H.; Pereira, F.; Rando, J.C. Five new extinct species of rails (Aves: Gruiformes: Rallidae) from the Macaronesian Islands (North Atlantic Ocean). Zootaxa 2015, 4057, 151-190. [CrossRef] [PubMed]

7. Bourne, W.R.P.; Ashmole, N.P.; Simmons, K.E.L. A new subfossil night heron and a new genus for the extinct rail from Ascension Island, central tropical Atlantic Ocean. Ardea 2003, 91, 45-51.

8. Kirchman, J.J.; Steadman, D.W. Rails (Rallidae: Gallirallus) from prehistoric archaeological sites in Western Oceania. Zootaxa 2006, 1316, 1-31. [CrossRef]

9. Livezey, B.C. Evolution of flightlessness in rails (Gruiformes: Rallidae): Phylogenetic, ecomorphological, and ontogenetic perspectives. Ornithol. Monogr. 2003, 53, 1-654. [CrossRef]

10. Matsuoka, H. The Late Pleistocene fossil birds of the central and southern Ryukyu Islands, and their zoogeographical implications for the recent avifauna of the archipelago. Tropics 2000, 10, 165-188. [CrossRef]

11. Olson, S.L. A classification of the Rallidae. Wilson Bull. 1973, 85, 381-416.

12. Taylor, B.; van Perlo, B. Rails. A Guide to the Rails, Crakes, Gallinules and Coots of the World; Pica Press: Sussex, UK, 1998; 600p.

13. Kirchman, J.J.; Steadman, D.W. Rails (Aves: Rallidae: Gallirallus) from prehistoric sites in the Kingdom of Tonga, including a description of a new species. Proc. Biol. Soc. Wash. 2005, 118, 465-477. [CrossRef]

14. Olson, S.L.; Wingate, D.B. Two new species of flightless rails (Aves: Rallidae) from the Middle Pleistocene "crane fauna" of Bermuda. Proc. Biol. Soc. Wash. 2000, 113, 356-368.

15. Olson, S.L.; Wingate, D.B. A new species of large flightless rail of the Rallus longirostris/elegans complex (Aves: Rallidae) from the Late Pleistocene of Bermuda. Proc. Biol. Soc. Wash. 2001, 114, 509-516.

16. Takano, O.M.; Steadman, D.W. Another new species of flightless rail (Aves: Rallidae: Rallus) from Abaco, The Bahamas. Zootaxa 2018, 4407, 376-382. [CrossRef] [PubMed]

17. Anderson, A. Archaeology of the coastal sites on Rapa Island. Terra Aust. 2012, 37, 47-76.

18. Baumel, J.J.; Witmer, L.M. Osteologia. In Handbook of Avian Anatomy: Nomina Anatomica Avium; Baumel, J.J., King, A.S., Breazile, J.E., Evans, H.E., Vanden Berge, J.C., Eds.; Nuttall Ornithological Club: Cambridge, UK, 1993; pp. 45-132.

19. Gilbert, B.M.; Martin, L.D.; Savage, H.G. Avian Osteology; Modern Printing: Laramie, WY, USA, 1981 ; p. 252. 
20. Livezey, B.C.; Zusi, R.L. Higher-order phylogeny of modern birds (Theropoda, Aves: Neornithes) based on comparative anatomy. II. Analysis and discussion. Zool. J. Linn. Soc. 2007, 149, 1-95. [CrossRef]

21. Winkler, D.W.; Billerman, S.M.; Lovette, I.J. Rails, gallinules, and coots (Rallidae), version 1.0. In Birds of the World; Billerman, S.M., Keeney, B.K., Rodewald, P.G., Schulenberg, T.S., Eds.; Cornell Lab of Ornithology: Ithaca, NY, USA, 2020. [CrossRef]

22. Kirchman, J.J.; McInerney, N.R.; Giarla, T.C.; Olson, S.L.; Slikas, E.; Fleischer, R.C. Phylogeny based on ultra-conserved elements clarifies the evolution of rails and allies (Ralloidea) and is the basis for a revised classification. Ornithology 2021, 138, 1-21. [CrossRef]

23. Kirchman, J.J.; McInerney, N.R.; Giarla, T.C.; Olson, S.L.; Slikas, E.; Fleischer, R.C. Corrigendum to: Phylogeny based on ultraconserved elements clarifies the evolution of rails and allies (Ralloidea) and is the basis for a revised classification. Ornithology 2021, 138, ukab065. [CrossRef]

24. Kirchman, J.J.; Steadman, D.W. New species of extinct rails (Aves: Rallidae) from archaeological sites in the Marquesas Islands, French Polynesia. Pac. Sci. 2007, 61, 145-163. [CrossRef]

25. Worthy, T.H.; Burley, D.V. Prehistoric avifaunas from the Kingdom of Tonga. Zool. J. Linn. Soc. 2020, 189, 998-1045. [CrossRef]

26. Steadman, D.W.; Bollt, R. Prehistoric Birds from Rurutu, Austral Islands, East Polynesia. Pac. Sci. 2010, 64, 315-325. [CrossRef]

27. Worthy, T.H.; Bollt, R. Prehistoric birds and bats from the Atiahara Site, Tubuai, Austral Islands, East Polynesia. Pac. Sci. 2011, 65, 69-85. [CrossRef]

28. Kirchman, J.J.; Steadman, D.W. New species of rails (Aves: Rallidae) from an archaeological site on Huahine, Society Islands. Pac. Sci. 2006, 60, 281-297. [CrossRef]

29. Steadman, D.W. Extinction of birds in Eastern Polynesia: A review of the record, and comparisons with other Pacific Island groups. J. Archaeol. Sci. 1989, 16, 177-205. [CrossRef]

30. Steadman, D.W. Prehistoric extinctions of Pacific island birds: Biodiversity meets zooarchaeology. Science 1995, $267,1123-1131$. [CrossRef] [PubMed]

31. Seitre, R.; Seitre, J. Causes of land-bird extinctions in French Polynesia. Oryx 1992, 26, $215-222$.

32. Thibault, J.-C.; Varney, A. Numbers and habitat of the Rapa fruit-dove, Ptilinopus huttoni. Bird Conserv. Int. 1991, 1, 75-81. [CrossRef]

33. Holyoak, D.T.; Thibault, J.-C. Contribution à L'étude des Oiseaux de Polynésie Orientale. Mémoires du Muséum National D’Histoire Naturelle Série A Zoologie 1984, 127, 1-209.

34. Thibault, J.-C.; Varney, A. Breeding seabirds of Rapa (Polynesia): Numbers and changes during the 20th century. Bull. Br. Ornithol. Club 1991, 111, 70-77.

35. Olson, S.L. Evolution of the rails of the South Atlantic islands (Aves: Rallidae). Smithson. Contrib. Zool. 1973, 152, 1-53. [CrossRef]

36. García-R, J.C.; Gibb, G.C.; Trewick, S.A. Deep global evolutionary radiation in birds: Diversification and trait evolution in the cosmopolitan bird family Rallidae. Mol. Phylogenet. Evol. 2014, 81, 96-108. [CrossRef] [PubMed]

37. García-R, J.C.; Gibb, G.C.; Trewick, S.A. Eocene diversification of crown group rails (Aves: Gruiformes: Rallidae). PLoS ONE 2014, 9, e109635. [CrossRef] [PubMed]

38. Kirchman, J.J. Speciation of flightless rails on islands: A DNA-based phylogeny of the typical rails of the Pacific. Auk 2012, 129, 56-69. 